\title{
Implementation of Data Mining Using C4.5 Algorithm for Predicting Customer Loyalty of PT. Pegadaian (Persero) Pati Area Office
}

\author{
$1^{\text {st }}$ Ridlo Muttaqien, $2^{\text {nd }}$ Musthofa Galih P, $3^{\text {rd }}$ Andri Pramuntadi \\ ${ }_{1,2,3}$ Computer Science/Informatics \\ 1,2,3 Alma Ata University Yogyakarta, Indonesia \\ 173200015@almaata.ac.id, mgalihpradana@almaata.ac.id,andripramuntadi@almaata.ac.id.
}

\begin{abstract}
PT Pegadaian (Persero) is engaged in the business of providing credit services with pawn, non-pawning and gold investment products. One of the right marketing strategies to survive today's high competition is to maintain customer loyalty, researchers use several data variables available in the MIS (Management Information System) in the form of customer transaction frequency, how many products are taken by customers, customer satisfaction and direct interviews. to predict customer loyalty of PT Pegadaian (Persero) by implementing the c4.5 algorithm. The c4.5 algorithm is the algorithm used to create a decision tree. Decision trees are a very powerful and well-known method of classification and prediction. The decision tree method converts very large facts into a decision tree that represents the rule. Rules can be easily understood in natural language. This study aims to determine the accuracy of the C4.5 algorithm to predict customer loyalty of PT Pegadaian (Persero) and the most influential factors in loyalty. The results of the experimental application of the c4.5 algorithm show that the level of accuracy generated in predicting customer loyalty is quite high, namely $89.94 \%$ in data testing 1 and $94 \%$ in data testing 2. The application of the c4.5 algorithm in predicting customer loyalty of PT Pegadaian (Persero) can be well applied.
\end{abstract}

Keywords : C4.5 algorithm, Loyalty, Rapidminer.

\section{INTRODUCTION}

PT Pegadaian (Persero) is one of the many financial institutions managed by BUMN. PT Pegadaian (Persero) is engaged in the business of providing credit services to Indonesian citizens with pawn, non-pawning and gold investment products. Currently, PT Pegadaian (Persero) is experiencing very tight challenges. These challenges arise as many credit lender services appear that offer lower interest rates and easy terms. PT Pegadaian (Persero) has challenges on how to retain customers.

Loyalty is a deeply held commitment to repurchase or subscribe to products and services in the future despite situational influences. According to [1] there are six reasons why companies need to maintain customer loyalty. First: existing customers are more prospective, meaning that loyal customers will provide large benefits to the institution. Second: the cost of acquiring new customers is much greater than keeping and retaining existing customers. Third: customers who already believe in the company in one matter will believe in other matters. Fourth: the company's operating costs will be efficient if it has many loyal customers. Fifth: the company can reduce psychological and social costs because old customers have had many positive experiences with institutions. Sixth: loyal customers will always defend the company and even try to attract and advise others to become customers.

PT Pegadaian (Persero) has a web-based information system, namely MIS (Management Information System) in which the company can monitor information used in planning, controlling, and continuous improvement such as increasing and decreasing customer status with several requests and reasons, and customer non-performing credit records. , and customer transaction records. The MIS (Management Information System) that is running is already computerized and already has a database to store company management data.
To find out the factors that influence customer loyalty from PT Pegadaian (Persero) customers based on the data in the MIS (Management Information System), the researcher uses several data variables available in the MIS (Management Information System) in the form of customer transaction frequency, how many products are available. taken by customers and conduct interviews directly to predict customer loyalty of PT Pegadaian (Persero) by implementing the c.45 algorithm to calculate the data.

\section{RESEARCH METHODS}

The author uses the C 4.5 algorithm on the basis of some literature from previous research from Teguh Budi Santoso with the title "Analisa Dan Penerapan Metode C4.5 Untuk Prediksi Loyalitas Pelanggan" with the results showing that classification with the $\mathrm{C} 4.5$ algorithm gets an accuracy of up to $97.5 \%$, which means that the exact $\mathrm{C} 4.5$ algorithm is used to calculate the level of customer loyalty [1]. The second study entitled "Penerapan Algoritma C4.5 Untuk Prediksi Loyalitas Nasabah PT Erdika Elit Jakarta" by Khotibul Umam, based on the decision tree that has been made the attribute that has the most influence on customer loyalty is educational background because it has the highest gain value, namely 1.545292721 and as the root of the decision tree while the gender of the customer does not have much effect on customer loyalty because it is always at the last node with a gain value of 0.623919119 [2]. The third study entitled "Penerapan algortima c4.5 untuk penentuan kelayakan kredit" by Siti Nur Khasanah, Based on the results of the application of the C4.5 classifier algorithm, it can be concluded that to determine credit worthiness whether a prospective customer will become a customer with smooth or problematic payments using the C4.5 algorithm classifier and the accuracy of the C4.5 classifier algorithm using training data for 270 customers is $88.52 \%$ [3]. The fourth study entitled "Pengambilan Keputusan Pegawai Tidak Tetap Menjadi Pegawai Tetap 
Peer Reviewed - International Journal

Vol : Vol. 02, Issue 03, August 2021

e-ISSN : 2745-9659

https://ijcis.net/index.php/ijcis/index

Dengan Decission Tree" by Febryantahanuji, By using the C4.5 algorithm and testing methods using X-Fold Cross Validation can help companies to create a decision support system for the appointment of non-permanent employees to become permanent employees, because the main indicators are obtained in determining permanent employees [4]. The fifth study entitled "Penerapan Algoritma C4.5 untuk Penentuan Kelayakan Pemberian Kredit" by Teguh Budi Santoso, that the results of the classification using the C4.5 Algorithm show that an accuracy of $97.5 \%$ is obtained, based on the results obtained. The results obtained indicate that the c4.5 algorithm is suitable to be used to determine the feasibility of giving [5]. The sixth study entitled "Implementasi Algoritma C4. 5 terhadap Kepuasan Pelanggan, by Harry Dika, the results of this study resulted in the formation of a fast food restaurant satisfaction model, the level of accuracy produced was quite high and included in the very good category [6].

Data mining is a method for finding data in a large database. Data mining is the process of analyzing and extracting data in the database to obtain useful new data, become new patterns or patterns, and to calculatepredictions. Classification and prediction are two forms of data analysis that can be used to extract models from data containing classes or to predict future data trends. Classification predicts data in the form of categories, while prediction models functions of continuous values. For example, a classification model can be made to classify loan applications to banks as risky or safe, while a predictive model can be made to predict expenses for buying computer equipment from potential customers based on their income and location of residence.[7]

$\mathrm{C} 4.5$ algorithm is an algorithm used to generate a decision tree. The workflow of the $\mathrm{C} 4.5$ algorithm is making a decision tree based on the selection of the attribute that has the highest priority or that has the highest gain value based on the value of the entropy attribute as the axis of the classification attribute. At this stage the C4.5 algorithm has 2 working rules, namely: Making a decision tree, and making rules (rule model). The rules formed from the decision tree will form a condition in the form of if then.[8]

Calculate entropy :

$$
\operatorname{Entropy}(S)=\sum_{i=1}^{n}\left(-p_{i}\right) * \log _{2}\left(p_{i}\right)
$$

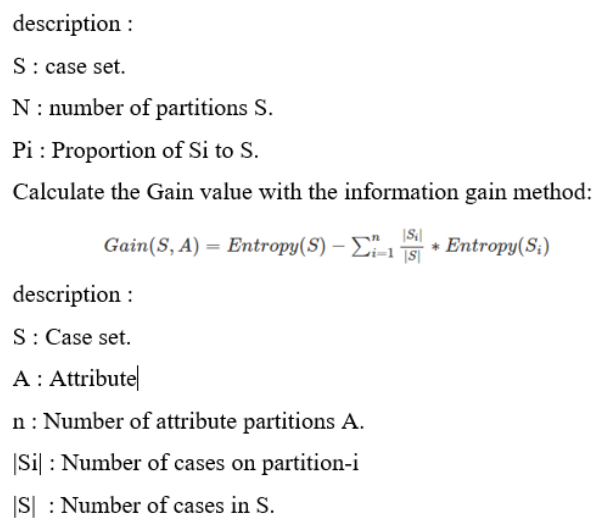

Figure 1. C4.5 Algoritm Formula

\subsection{Design}

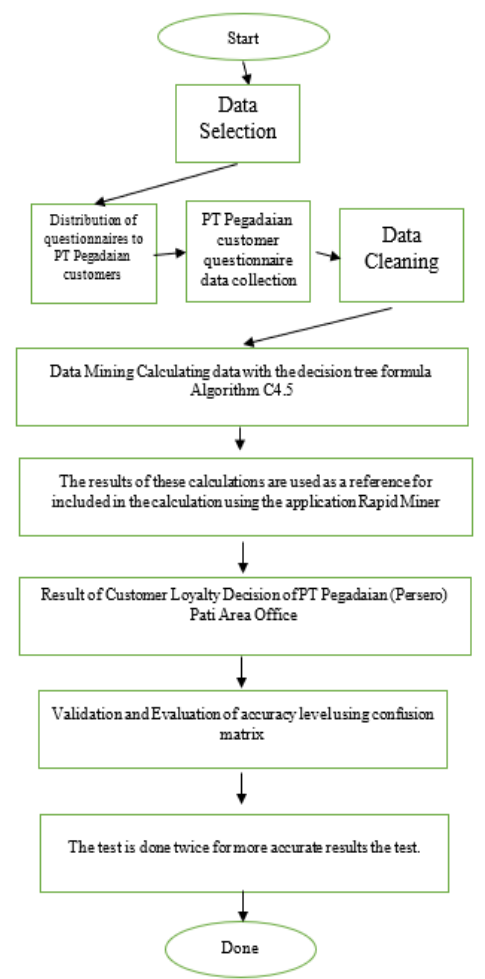

Figure 2. Research Design

\subsection{Research Variables}

In this study the authors use research variables to measure customer loyalty of PT Pegadaian (Persero) which is divided into six categories, namely: frequency of transactions, how many products are taken, customer satisfaction, age and gender of customers. The following variables are used and their descriptions :

Table 1. Research Variables Table

\begin{tabular}{|l|l|}
\hline \multicolumn{1}{|c|}{ Category } & \multicolumn{1}{c|}{ Information } \\
\hline Transaction frequency & How often do customers transact \\
\hline Product taken & The number of products taken by customers \\
\hline Customer satisfaction & Customer satisfaction level \\
\hline Gender & Customer gender \\
\hline Age & Age of customer \\
\hline
\end{tabular}

\section{RESULT AND ANALYSIS}

\subsection{Data Selection}

The data used in this study is the source of data from MIS Pegadaian and questionnaires. Data were obtained from the distribution of 166 questionnaires. Questionnaire data is data distributed to customers of PT Pegadaian (Persero) Pati area office in March - June 2021 with variable frequency of transactions, how many products are taken, customer satisfaction level, age and gender of the customer.

\subsection{Data Cleaning}

The data obtained from the respondents will be selected first, in order to obtain data that is in accordance with the 
Peer Reviewed - International Journal

Vol : Vol. 02, Issue 03, August 2021

e-ISSN : 2745-9659

https://ijcis.net/index.php/ijcis/index

needs of the researcher. Of the 200 data obtained, 170 data were complete and correct, the remaining 166 data were not included because there was incomplete data when filling out the questionnaire and it was not filled in according to the existing instructions.

\subsection{Data Training}

The results of the training data are used to obtain the results of the level of customer loyalty in the form of a decision tree.

Table 2. Data Training

\begin{tabular}{|c|c|c|c|c|c|}
\hline $\begin{array}{c}\text { Age } \\
\text { Of } \\
\text { Customer }\end{array}$ & $\begin{array}{c}\text { Gender Of } \\
\text { Customer }\end{array}$ & $\begin{array}{c}\text { Product } \\
\text { Taken }\end{array}$ & $\begin{array}{c}\text { Transaction } \\
\text { Frequency }\end{array}$ & $\begin{array}{c}\text { Customer } \\
\text { Satisfication }\end{array}$ & $\begin{array}{c}\text { Result } \\
\text { Of } \\
\text { loyalty }\end{array}$ \\
\hline Adult & Male & 1 & Often & Satisfied & Yes \\
\hline Adult & Male & 1 & Often & Satisfied & Yes \\
\hline Old & Female & 1 & not often & Netral & No \\
\hline Old & Male & 2 & not often & Netral & Yes \\
\hline Adult & Female & 1 & not often & Satisfied & Yes \\
\hline Teenager & Male & 2 & Often & Satisfied & Yes \\
\hline Teenager & Male & 2 & not often & Not satisfied & No \\
\hline Teenager & Female & 1 & Often & Not satisfied & No \\
\hline Old & Female & 2 & Often & satisfied & Yes \\
\hline$\ldots .$. & $\ldots .$. & $\ldots .$. & $\ldots .$. & $\ldots .$. & $\ldots . .$. \\
\hline
\end{tabular}

Then calculate the entropy of each attribute and gainvalue with the $\mathrm{C} 4.5$ algorithm formula which results:

Table 3. Result of Decision Tree

\begin{tabular}{|c|c|c|c|c|c|c|}
\hline Attribute & & $\begin{array}{l}\text { Total } \\
\text { Case }\end{array}$ & No & Yes & Entropy & Gain \\
\hline Total & & 66 & 28 & 38 & 0,98337619 & \\
\hline \multirow{4}{*}{ Umur } & & & & & & 0,02148474 \\
\hline & Teenager & 16 & 7 & 9 & 0,988699408 & \\
\hline & Adult & 39 & 14 & 25 & 0,941828535 & \\
\hline & Old & 11 & 5 & 6 & 0,994030211 & \\
\hline \multirow{3}{*}{$\begin{array}{l}\text { Customer } \\
\text { Gender }\end{array}$} & & & & & & 0,00442794 \\
\hline & Male & 36 & 14 & 22 & 0,964078765 & \\
\hline & Female & 30 & 14 & 16 & 0,996791632 & \\
\hline \multirow{4}{*}{$\begin{array}{c}\text { Product } \\
\text { Taken }\end{array}$} & & & & & & 0,247643891 \\
\hline & 1 & 41 & 26 & 15 & 0,947435136 & \\
\hline & 2 & 18 & 1 & 17 & 0,309543429 & \\
\hline & 3 & 7 & 1 & 6 & 0,591672779 & \\
\hline \multirow{3}{*}{$\begin{array}{l}\text { Frequency } \\
\text { Transaction }\end{array}$} & & & & & & 0,414352159 \\
\hline & Often & 32 & 2 & 30 & 0,337290067 & \\
\hline & Not Often & 34 & 26 & 8 & 0,787126586 & \\
\hline \multirow{3}{*}{$\begin{array}{l}\text { Customer } \\
\text { Satisfication }\end{array}$} & & & & & & 0,479549994 \\
\hline & $<=2$ & 32 & 26 & 6 & 0,69621226 & \\
\hline & $=>2$ & 34 & 2 & 32 & 0,322756959 & \\
\hline
\end{tabular}

From the results of the manual calculation above, it is found that the customer satisfaction variable gets the highest gain value and is used as the root node of the decision tree and is calculated again with the rapidminer application.

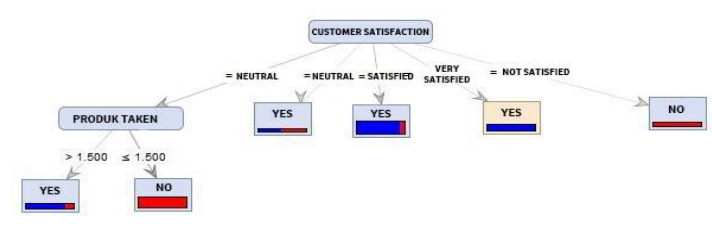

Figure 3. Decision Tree

\subsection{Data Testing 1}

This test is done by dividing as much as 2 parts of the testing data to be tested. Test 1 uses 50 training data, and in this test will produce values of accuracy, precision, and recall.

Table 4. Data Testing 1

\begin{tabular}{|c|c|c|c|c|c|}
\hline $\begin{array}{c}\text { Age } \\
\text { Of } \\
\text { Customer }\end{array}$ & $\begin{array}{c}\text { Gender Of } \\
\text { Customer }\end{array}$ & $\begin{array}{c}\text { Product } \\
\text { Taken }\end{array}$ & $\begin{array}{c}\text { Transaction } \\
\text { Frequency }\end{array}$ & $\begin{array}{c}\text { Customer } \\
\text { Satisfication }\end{array}$ & $\begin{array}{c}\text { Result } \\
\text { Of } \\
\text { loyalty }\end{array}$ \\
\hline Adult & Male & 1 & Often & Satisfied & Yes \\
\hline Adult & Male & 1 & Often & Satisfied & Yes \\
\hline Old & Female & 1 & not often & Netral & No \\
\hline Old & Male & 2 & not often & Netral & Yes \\
\hline Adult & Female & 1 & not often & Satisfied & Yes \\
\hline Teenager & Male & 2 & Often & Satisfied & Yes
\end{tabular}

From the decision tree implementation table above, then enter the validation process with $\mathrm{x}$ validation in rapidminer. And the result is as follows:

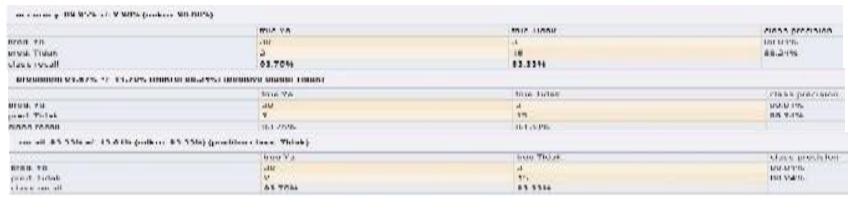

Figure 4. Calculation of Rapid Miner Data Testing 1

From the data validation process testing 1, the results obtained are: True Positive (TP) totaling 30 data, True Negative (TN) 15 data, False Positive (FP) 3 data, False Negative (FP) 2 data, which means that TP has 30 data with the result loyal and loyal prediction results, FP 3 data with loyal results but disloyal predictions, FN 2 data with disloyal results but loyal predictions, TN with disloyal results and disloyal predictions. And obtained 89.95\% accuracy, $91.67 \%$ precision, and $83.33 \%$ recall.

Table 5. Result Rapid Miner Data Testing 1

\begin{tabular}{|l|l|l|}
\hline \multicolumn{1}{|c|}{$\mathbf{N}=\mathbf{5 0}$} & \multicolumn{1}{c|}{ Aktual : Yes } & \multicolumn{1}{c|}{ Aktual : No } \\
\hline Prediction: Yes & TP: 30 & FP: 3 \\
\hline Prediction: No & FN: 2 & TN: 15 \\
\hline
\end{tabular}

\subsection{Data Testing 2}

This test is done by dividing as much as 2 parts of the testing data to be tested. Test 2 uses 50 training data, and in this test will produce values of accuracy, precision, and recall. 
Peer Reviewed - International Journal

Vol : Vol. 02, Issue 03, August 2021

e-ISSN : 2745-9659

https://ijcis.net/index.php/ijcis/index

Table 6. Data Testing 2

\begin{tabular}{|c|c|c|c|c|c|}
\hline $\begin{array}{c}\text { Age } \\
\text { Of } \\
\text { Customer }\end{array}$ & $\begin{array}{c}\text { Gender Of } \\
\text { Customer }\end{array}$ & $\begin{array}{c}\text { Product } \\
\text { Taken }\end{array}$ & $\begin{array}{c}\text { Transaction } \\
\text { Frequency }\end{array}$ & $\begin{array}{c}\text { Customer } \\
\text { Satisfication }\end{array}$ & $\begin{array}{c}\text { Result } \\
\text { Of } \\
\text { loyalty }\end{array}$ \\
\hline Adult & Male & 1 & Often & Satisfied & Yes \\
\hline Adult & Male & 1 & Often & Satisfied & Yes \\
\hline Old & Female & 1 & not often & Netral & No \\
\hline Old & Male & 2 & not often & Netral & Yes \\
\hline Adult & Female & 1 & not often & Satisfied & Yes \\
\hline Teenager & Male & 2 & Often & Satisfied & Yes
\end{tabular}

From the decision tree implementation table above, then enter the validation process with $\mathrm{x}$ validation in rapidminer. And the result is as follows:

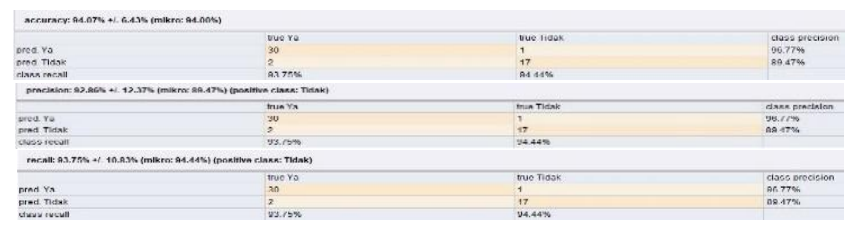

Figure 5. Calculation of Rapid Miner Data Testing2

From the data validation process testing 2, the results obtained: True Positive (TP) totaling 30 data, True Negative (TN) 17 data, False Positive (FP) 1 data, False Negative (FP) 2 data, which means that TP has 30 data with results loyal and loyal prediction results, FP 1 data with loyal results but disloyal predictions, FN 2 data with disloyal results but loyal predictions, TN 17 data with disloyal results and disloyal predictions. And obtained accuracy of $94.07 \%$, precision of $92.86 \%$, and recall of $94.44 \%$.

Table 7. Result Rapid Miner Data Testing 2

\begin{tabular}{|c|c|c|}
\hline $\mathrm{N}=50$ & Aktual $:$ Yes & Aktual $:$ No \\
\hline Prediction $:$ Yes & TP: 30 & FP: 1 \\
\hline Prediction $:$ No & FN: 2 & TN: 17 \\
\hline
\end{tabular}

\subsection{Result Customer Loyalty}

Of all the sample data there are 166 data, showing that there are 102 data with loyal results and 64 data with disloyal results. And from the hypothesis that has been tested, it shows that the variable customer satisfaction is very influential in customer loyalty at PT Pegadaian (Persero) Pati Area Office.

Table 8. Result Customer Loyalty

\begin{tabular}{|l|c|c|}
\hline \multicolumn{1}{|c|}{ Result } & Total & Presentation \\
\hline Loyal Customer & 102 & $61,5 \%$ \\
\hline Disloyal Customers & 64 & $38,5 \%$ \\
\hline
\end{tabular}

\section{IV.CONCLUSION}

Based on trials, evaluations and research results that researchers have done from the data collected regarding the use of the c4.5 algorithm method for predicting customer loyalty at PT Pegadaian (Persero) Pati area offices, it can be concluded that:

- The use of the C4.5 algorithm method can be used to predict customer loyalty of PT Pegadaian (Persero) area office.

- The formation of a customer loyalty model with a decision tree and customer satisfaction variable has the highest gain value and greatly influences customer loyalty.

- From the results of the evaluation using the confusion matrix, a high level of accuracy was obtained, namely $90 \%$ in testing data testing 1 and $94 \%$ in testing data testing 2 .

Based on the analysis that has been carried out and to improve performance and perfect the research that has been made, the researchers provide the following suggestions:

- Further research needs to be done by testing with other methods such as bayesian methods, clustering, neural networks, etc. to compare which results are more accurate.

- Adding more specific variables to customer loyalty for more accurate prediction results.

\section{THANK-YOU NOTE}

A big thank you to Alma Ata University which provided facilities in completing this research and to PT. Pegadaian (Persero) Kantor area Pati who provided theopportunity to conduct research and collect data.

\section{REFERENCES}

[1] T. B. Santoso, "ANALISA DAN PENERAPAN METODE C4.5 UNTUK PREDIKSI LOYALITAS PELANGGAN," J. Ilm. Fak. Tek. LIMIT'S, vol. 10, no. $1,2011$.

[2] K. Umam, D. Puspitasari, and A. Nurhadi, "Penerapan Algoritma C4.5 Untuk Prediksi Loyalitas Nasabah PT Erdika Elit Jakarta," J. Media Inform. Budidarma, vol. 4, no. 1, p. 65, 2020, doi: 10.30865/mib.v4i1.1652.

[3] S. N. Khasanah, "Penerapan algortima c4.5 untuk penentuan kelayakan kredit," vol. XIV, no. 1, pp. 914, 2017.

[4] H. D. P. Febryantahanuji, Irwan Sembiring, "Pengambilan Keputusan Pegawai Tidak Tetap Menjadi Pegawai Tetap Dengan Decission Tree," Joural Informatics Educ., vol. 1, no. 2, pp. 26-37, 2018.

[5] T. B. Santoso and D. Sekardiana, "Penerapan 
International Journal of Computer and Information System (IJCIS)

Peer Reviewed - International Journal

Vol : Vol. 02, Issue 03, August 2021

e-ISSN : 2745-9659

https://ijcis.net/index.php/ijcis/index

Algoritma C4.5 untuk Penentuan Kelayakan

Pemberian Kredit," J. Algoritm. Log. dan

Komputasi, vol. II, no. 1, pp. 130-137, 2019.

[6] H. Dhika, F. Destiawati, and A. Fitriansyah, "Implementasi Algoritma C4. 5 terhadap Kepuasan Pelanggan," pp. 80-86, 2018, doi: 10.31227/osf.io/fgc7a.

[7] S. Bayu, "DATA MINING KLASIFIKASI," Conv. Cent. Di Kota Tegal, vol. 4, no. 80, p. 4, 2018.

[8] A. R. Sukma, R. Halfis, and A. Hermawan, "Klasifikasi Channel Youtube Indonesia Menggunakan Algoritma C4.5," J. Tek. Komput., vol. V, no. 1, pp. 21-28, 2019, doi: 10.31294/jtk.v4i2. 